\title{
OCENA EFEKTU HARBERGERA-LAURSENA-METZLERA W POLSKIM SEKTORZE ROLNO-ŻYWNOŚCIOWYM
}

\author{
Jacek Strojny \\ Uniwersytet Rolniczy im. Hugona Kołłątaja w Krakowie, \\ Wydział Rolniczo-Ekonomiczny Katedra Statystyki i Ekonometrii \\ Kierownik Katedry: dr hab. Jacek Strojny
}

\begin{abstract}
Słowa kluczowe: terms of trade, rachunek obrotów bieżących, wektorowa autoregresja, polski sektor rolno-żywnościowy

Key words: terms of trade, current account, vector autoregression, Polish agro-food sector

JELcode: F19, N50, Q17

S y n o p s i s. W opracowaniu podjęto problem oszacowania efektu Harbergera-Laursena-Metzlera w odniesieniu do polskiego sektora rolno-żywnościowego. Analiza obejmuje lata 2002-2017. W badaniu zastosowano metodykę wektorowej autoregresji (VAR). Wyniki studium ukazały, że trwałe pogorszenie terms of trade wpływa na poprawę bilansu handlowego polskiego sektora rolno-żywnościowego. Natomiast nie zidentyfikowano skutków krótkookresowych szoków terms of trade. Dodatkowo, badanie umożliwiło zidentyfikowanie wartości dodanej brutto $(G V A)$ jako najbardziej egzogenicznej składowej systemu VAR. Najbardziej endogenicznym czynnikiem w modelu okazało się saldo obrotów bieżących. Długookresowe zmiany terms of trade są czynnikiem bardziej egzogenicznym niż saldo obrotów bieżących.
\end{abstract}

\section{WPROWADZENIE}

W przedstawionym opracowaniu podjęto próbę identyfikacji, a następnie oszacowania wielkości efektu Harbergera-Laursena-Metzlera (HLM) w odniesieniu do sektora rolno-żywnościowego w Polsce. Rozważania w tym zakresie prowadzone są na ogół na poziomie gospodarek narodowych. W tym przypadku podjęto problem występowania wspomnianego efektu na poziomie sektora gospodarki.

W teorii ekonomii poglądy odnośnie wpływu zmian terms of trade na bilans handlowy nie mają jednoznacznego charakteru. Najczęściej rozpatrywane wahania cenowe terms of trade (ToT) - oddziałują na saldo rachunku obrotów bieżących różnymi kanałami, a ostateczny rezultat zależy od wielu czynników. Na wynik zmian ToT ma wpływ charakter transmisji szoku cenowego (przybierający formę zmiany cenowych terms of trade), czas i natura trwania szoku (chwilowy lub trwały), przewidywania uczestników rynku odnośnie ewolucji relacji cenowych (zmiany oczekiwane bądź nieoczekiwane).

W pierwotnym ujęciu prezentowanym przez Svenda Laursena i Lloyda Metzlera oraz Arnolda Harbergera pogorszenie się cenowych terms of trade powinno prowadzić do zmniejszenia rzeczywistego dochodu z wymiany międzynarodowej [Laursen, Metzler 
1950, Harberger 1950]. Według S. Laursena i L. Metzlera, spadek wartości wskaźnika cenowego terms of trade, który może być na przykład skutkiem pogorszenia się relacji wymiennych dla waluty krajowej, wywołuje dwa przeciwne efekty absorpcyjne: efekt dochodowy i efekt substytucyjny. Efekt dochodowy wiąże się ze spadkiem dochodu $\mathrm{w}$ rezultacie pogorszenia cenowych terms of trade, co bezpośrednio limituje popyt krajowy. Przeciwne skutki generuje efekt substytucyjny. Stosownie do tego efektu zwyżka cen towarów importowanych skutkuje zastępowaniem coraz kosztowniejszego importu relatywnie taniejącymi produktami krajowymi. Skutkiem efektu substytucyjnego jest poprawa dobrostanu krajowego. Końcowy wynik oddziaływania zmiany terms of trade na saldo rachunku obrotów bieżących jest ustalany jako bilans wspomnianych efektów - dochodowego i substytucyjnego. Dominacja efektu substytucji wynikająca z pogarszającego się wskaźnika cenowego terms of trade implikuje polepszanie salda rachunku obrotów bieżących. Jeżeli jednak nad substytucyjnym przeważa efekt dochodowy, to należy oczekiwać pogorszenia salda rachunku obrotów bieżących.

Stosownie do koncepcji wiązanej z efektem HLM krótkookresowe pogorszenie relacji wymiennych w handlu międzynarodowym znajdujące odzwierciedlenie w zmniejszeniu wartości cenowych terms of trade prowadzi do pogorszenia salda bilansu obrotów bieżących, a w następstwie do spadku realnego dochodu. Stephen Turnovsky upatrywał źródeł pogorszenia się salda bilansu obrotów bieżących w rosnącej krańcowej skłonności do konsumpcji [Turnovsky 1997], a tym samym malejącej krańcowej skłonności do oszczędzania. Spadek oszczędności krajowych jest rezultatem zwiększania wydatków konsumpcyjnych celem podtrzymania przez konsumentów osiągniętego standardu życia na niezmienionym poziomie. Zatem krótkookresowa poprawa cenowych terms of trade powinna skutkować polepszeniem się salda bilansu obrotów bieżących. Abdur Chowdhury dopatrywał się uzasadnienia tej zależności w postawach konsumentów, którzy zwiększają oszczędności kosztem ograniczenia bieżących wydatków konsumpcyjnych [Chowdhury 2003]. Skłonność do ograniczenia konsumpcji wynika z uznania poprawy relacji wymiennych (cenowych terms of trade) i towarzyszącego im przyrostu dochodu jako sytuacji bez znamion trwałości.

\section{EFEKT HARBERGERA-LAURSENA-METZLERA W ŚWIETLE BADAŃ EMPIRYCZNYCH}

Od momentu publikacji pracy S. Laursena i L. Metzlera [Laursen, Metzler 1950], co pewien czas problem efektu HLM wzbudza w literaturze ekonomicznej znaczące zainteresowanie. Peijie Wang zaznaczył rolę teorii opisującej efekt HLM w ocenie skutków zmian kursu walutowego - w szczególności wpływu deprecjacji waluty krajowej na saldo bilansu handlowego [Wang 2009]. W teoretycznym ujęciu ważnym aspektem rozważań są skutki deprecjacji waluty krajowej ze względu na relatywne role efektów elastycznościowego i absorpcyjnego w kształtowaniu bilansu handlowego i płatniczego. Roberto Duncan dopatrywał się w literaturze ekonomicznej trzech typów podejścia do problematyki transmisji szoku w formie zmiany cenowych terms of trade [Duncan 2003], a mianowicie:

- łączenie wahań cenowych terms of trade ze zmianami salda bilansu obrotów bieżących jako wyniku zmiany sumarycznych oszczędności i wydatków konsumpcyjnych danego kraju; 
- niewiązanie w sposób jednoznaczny zmian cenowych terms of trade z modyfikacjami salda bilansu obrotów bieżących; zmiany rozmiarów oszczędności krajowych oraz inwestycji to wyraźnie zauważalne następstwo wahnięć cenowych ToT;

- antycypowanie związku między zmianami cenowych terms of trade a poziomem wydatków publicznych, co pośrednio wpływa na bilans płatniczy. Zmiana salda bilansu obrotów bieżących wynika w tym ujęciu ze zmiany salda budżetu państwa stosownie do koncepcji deficytów bliźniaczych [Tornell, Lane 1994].

Efekt HLM zakłada, że dla gospodarki otwartej egzogeniczny wzrost wskaźnika terms of trade zasadniczo prowadzi do poprawy bilansu handlowego kraju. Wielu naukowców zajmujących się tą problematyką na podstawie obserwacji empirycznych wspierało tezę o występowaniu efektu HLM. Wyniki uzyskiwane przez innych w studiach nad zmianami bilansu handlowego i ich skutkami dla dochodu realnego w odpowiedzi na szok wyprowadzany z terms of trade były zbieżne z symulacjami dokonanymi przez Enrique Mendozę na podstawie dynamicznego modelu stochastycznego równowagi ogólnej dla gospodarki otwartej [Mendoza 1995].

Pozytywny związek między krótkookresowym zwiększeniem się wskaźnika cenowego terms of trade a poprawą salda bilansu handlowego opartego na modelu wektorowej autoregresji stwierdził Glenn Otto [Otto 2003]. Obserwacje te dotyczyły zarówno wybranych do próby badawczej piętnastu krajów OECD, jak i krajów rozwijających się. Potwierdzenie występowania efektu HLM stwierdził Jeffrey Sachs [Sachs 1981]. Jednak obserwacje te dotyczyły jedynie krótkookresowych zmian terms of trade, nie odnosiły się do skutków trwałych zmian wskaźnika cenowego terms of trade. Zależności mają bardziej zawikłany charakter, jeśli długookresowe zmiany cenowych terms of trade oddziałują jedynie na poziom konsumpcji, a nie wpływają na zmianę poziomu oszczędności. Koncepcję wiążącą szoki terms of trade ze stanem bilansu handlowego wsparli w opracowaniu Carmen Reinhart i Jonathan Ostry [Reinhart, Ostry 1991].

Koncepcję tę krytycznej ocenie poddał Maurice Obstfeld [Obstfeld 1981], wykorzystując funkcję użyteczności wiążącą preferencję wobec czasu z użytecznością $\mathrm{w}$ ujęciu Hirofumi Uzawy [Uzawa 1968], doszedł do wniosków zasadniczo sprzecznych z klasycznym ujęciem efektu HLM. M. Obstfeld sugerował wzrost oszczędności krajowych w odpowiedzi na pogorszenie się terms of trade jako dostosowanie się do konieczności gromadzenia zagranicznych aktywów przy obniżającym się realnym dochodzie.

Torsten Persson i Lars Svensson poszukiwali zagrożeń dla optymalnego poziomu bilansu wymiany ekonomicznej z zagranicą oraz teoretycznego uzasadnienia przepływów kapitału w skali międzynarodowej [Persson, Svensson 1985], traktując rachunek bieżący jako różnicę między krajowymi oszczędnościami i inwestycjami, co odbiega od tradycyjnego ujęcia efektu HLM, które koncentruje się na wpływie zmian w handlu na oszczędności. Koncepcja wprowadzona przez A. Harbergera oraz S. Laursena i L. Metzlera opiera się na ujęciu statycznym oszczędności i postuluje spadek relacji oszczędności do rzeczywistego dochodu przy pogarszaniu się terms of trade.

R. Duncan zauważył, że skutek szoku cenowych terms of trade dla bilansu rachunków bieżących może być różny w zależności, czy zmiany były oczekiwane przez rynek oraz czy mają one charakter krótkookresowy bądź długookresowy [Duncan 2003]. Problem rozróżnienia skutków trwałych i czasowych szoków terms of trade podkreślali również Lars Svensson i Assaf Razin [Svensson, Razin 1983], którzy podzielali opinię, że krótkookresowy szok terms of trade skutkuje spadkiem dochodu. Jednak wolniejszy spadek 
konsumpcji prowadzi do pogorszenia salda obrotów bieżących. Natomiast zmniejszenie długookresowe terms of trade skutkuje spadkami w równych proporcjach - zarówno dochodu, jak i konsumpcji. Nie ma to jednoznacznego wpływu na poziom oszczędności, co jest związane z charakterem funkcji preferencji konsumentów.

Pewna grupa opracowań nie wspiera tezy o związku między zmianami cenowych terms of trade a zmianami salda bilansu obrotów bieżących. W miejsce wspomnianej relacji, na podstawie obserwacji empirycznych, niektórzy badacze łączyli szoki cenowych terms of trade z wahaniami poziomu oszczędności ludności. Theo S. Eicher, Stefan F. Schubert i S. Turnovski zasugerowali, że sposób reakcji danego kraju na szoki cenowych terms of trade wynika głównie ze stanu bilansu płatniczego [Eicher i in. 2008]. Odmienne zachowania wykazują kraje $\mathrm{z}$ nadwyżką $\mathrm{w}$ tym zakresie, a inne reakcje kraje zadłużone netto w relacji do zagranicy. Różnic w tym zakresie badacze upatrywali w przepływach kapitału powodowanych zmianami terms of trade. Niemniej, w opracowaniach wskazywano na wpływ nawet relatywnie niedużego pogorszenia cenowego wskaźnika terms of trade na zmniejszenie dobrobytu państwa.

Sebastian Edwards na podstawie badań bazujących na ogólnym modelu równowagi międzyokresowej analizował powiązania szoków cenowych terms of trade z wahaniami kursów walutowych oraz saldem bilansu handlowego [Edwards 1989], wnioskując, że krótkotrwałe wahania cenowych terms of trade mają niewątpliwy wpływ na poziom oszczędności prywatnych. Pogorszenie relacji wymiennych (odzwierciedlane przez spadek cenowego wskaźnika terms of trade) może prowadzić do odraczania przez konsumentów terminu zakupów na przyszłość i zwiększenia oszczędności jako skutku rosnącego kosztu importu. Pogorszenie relacji wymiennych może prowadzić także do względnego wzrostu cen towarów importowanych w porównaniu do cen towarów niewymienialnych na rynku międzynarodowym. Tego typu pogorszenie wskaźnika ToT może prowadzić do realnej aprecjacji waluty krajowej. W dalszej perspektywie towarzyszący tym zjawiskom wzrost stopy procentowej stymuluje konsumentów do odroczenia konsumpcji bieżącej i zwiększenia zasobów oszczędności.

\section{METODYKA BADAŃ}

Szacunki wpływu ToT polskich produktów rolno-żywnościowych na bilans handlowy dla tej kategorii towarowej oparto na metodyce wektorowej autoregresji (VAR). Model VAR (nie poddany ograniczeniom) w formie zwartej przyjmuje postać [Charemza, Deadman 1997, Kusideł 2000, Lütkepohl 1991]:

$$
\mathbf{x}_{t}=A_{0} \mathbf{D}_{t}+\sum_{i=1}^{k} \mathbf{A}_{k} \mathbf{x}_{t-k}+\mathbf{e}_{t}, \quad t=1,2, \ldots, T
$$

gdzie:

$\mathbf{x}_{t}$ - wektor obserwacji na wartościach $n$ zmiennych modelu,

$\mathbf{D}_{t}$ - wektor składników deterministycznych,

$A_{0}$ - parametry przy zmiennych wektora $D_{t}$,

$\mathbf{A}_{i}-$ macierze parametrów przy opóźnionych zmiennych wektora $x_{t}$,

$\mathbf{e}_{t}-$ wektory zakłóceń losowych. 
W przypadku, gdy badanie kointegracyjne (umożliwiające określenie charakteru relacji między zmiennymi) nie identyfikuje istnienia zależności długookresowych, do oceny procesów krótkookresowych można wykorzystać następujący model VAR dla przyrostów zmiennych:

$$
\Delta \mathbf{x}_{t}=A_{0} \mathbf{D}_{t}+\sum_{i=1}^{k} \mathbf{A}_{i} \Delta \mathbf{x}_{t-i}+\mathbf{e}_{t}, \quad t=1,2, \ldots, T ;
$$

gdzie:

$\mathbf{x}_{t}-$ wektor pierwszych różnic zmiennych objaśnianych $\mathbf{x}_{t}=\left[x_{t 1}, x_{t 2}, \ldots, x_{t n}\right]^{\mathrm{T}}$.

Analizę kointegracyjną wykonywano metodą Johansena [Johansen 1988], która do badania relacji kointegracyjnych wykorzystuje modele VAR (przekształcone do postaci modelu korekty błędem). Badanie kointegracji zasadzało się na identyfikacji rzędu macierzy $\Pi \mathrm{w}$ teście Johansena. Rząd macierzy $\Pi \mathrm{W}$ tej procedurze jest równy liczbie niezależnych wektorów kointegracyjnych. Gdy rząd macierzy $\Pi$ wynosi $0(R=0)$, w relacji nie występują zależności długookresowe i model korekty błędem (VECM) użyty do badania kointegracji sprowadza się do modelu VAR dla przyrostów zmiennych o równaniu (2). Dla $(R=M)$, co oznacza pełny rząd macierzy $\Pi$, zerowy stopień zintegrowania zmiennych wiążący się z ich „łączną stacjonarnością” podważa celowość analizy kointegracyjnej. Implikuje to użycie modelu VAR dla poziomów zmiennych w formie równania (1).

Modele VAR odwołują się do stacjonarnych zmiennych. Dlatego ocenę tego aspektu szeregów czasowych przeprowadzono z użyciem testu KPSS (testu Kwiatkowskiego-Phillipsa-Schmidta-Shina) [Kwiatkowski i in. 1992]. Po oszacowaniu parametrów modelu zidentyfikowanego na etapie analizy kointegracyjnej przeprowadzono analizę przyczynowości oraz określenie priorytetu zmiennych w systemie VAR. Do weryfikacji hipotez ekonomicznych o charakterze relacji zmiennych, jak: wskaźnik terms of trade, bilans handlowy oraz wartość dodana brutto sektora rolnego, posłużyły testy przyczynowości, analiza funkcji odpowiedzi na impuls $(I R F)$ oraz dekompozycja wariancji błędu prognozy.

Analizę przyczynowości (w sensie Grangera) przeprowadzano stosując test $F$ dla hipotezy o braku restrykcji. W tym ujęciu jeżeli pewna zmienna jest przyczyną innej, to implikuje to kierunek związku przyczynowo-skutkowego [Charemza, Deadman 1992, Osińska 2006]. Hipoteza zerowa testu $F$ zakłada, że dana zmienna nie jest przyczyną zmiennej objaśnianej w równaniu. Niskie wartości istotności (przyjęto $<0,05$ ) pozwalają na odrzucenie hipotezy zerowej, co należy interpretować w kategoriach wpływu rozpatrywanej zmiennej na zmienną objaśnianą w danym równaniu systemu VAR.

Zgodnie $\mathrm{z}$ ideą metodyki wektorowej autoregresji każda ze zmiennych w modelu jest zmienną objaśnianą. W modelu VAR nie obowiązuje klasyczny podział na zmienne endogeniczne i egzogeniczne. Po ustaleniu charakteru wpływu poszczególnych zmiennych na modelowany system stosuje się termin zmienna „bardziej egzogeniczna” bądź „mniej egzogeniczna".

Analizę przyczynowości rozszerza dekompozycja wariancji błędu prognozy. Jest ona pomocna w określeniu udziału zmiennych włączonych do modelu w objaśnianiu wariancji błędu prognozy rozważanej zmiennej. Analiza może posłużyć do określenia istotności zmiennych w wyjaśnianiu badanych współzależności. Należy mieć na uwa- 
dze, że kolejność równań systemu VAR może determinować w pewnym stopniu udziały komponentów analizy dekompozycji wariancji (pierwsza zmienna modelu zyskuje status najbardziej niezależnej). Kolejne zmienne modelu wpływają bezpośrednio na wszystkie pozostałe poza czynnikami je poprzedzającymi. Może to uzasadniać rozpatrywanie różnych scenariuszy kompozycji modelu VAR - możliwych i uzasadnionych teoretycznie wariantów porządku równań. Przyjęcie w badaniu kolejności równań ze zmienną terms of trade na pierwszej pozycji w modelu VAR skutkuje założeniem, że zmienna ta jest najbardziej niezależną od pozostałych. Szacunki udziału poszczególnych zmiennych w objaśnianiu zmiennej zależnej w danym równaniu dotyczą udziałów w wariancji błędu prognoz modelowanej zmiennej. Niskie udziały zmiennych objaśniających w analizie dekompozycji świadczą o znacznym stopniu niezależności kształtowania się zmiennej objaśnianej w relacji do odpowiedniej zmiennej objaśniającej.

Równolegle do analizy dekompozycji wariancji przeprowadzono analizę funkcji odpowiedzi na impuls $(I R F)$, która umożliwia scharakteryzowanie oddziaływań między zmiennymi w czasie. Rezultaty obu badań powinny prowadzić do podobnych konkluzji i uzupełniać się. Funkcja odpowiedzi na impuls ukazuje rozkład w czasie reakcji zmiennej objaśnianej w równaniu na impuls z pozostałych zmiennych systemu VAR. Analiza funkcji odpowiedzi na impuls umożliwia rozszerzenie analizy przyczynowości o ustalenie kierunku oddziaływania przyczyny, ocenę siły impulsu i szybkości jego wygasania oraz rozkładu procesu w czasie.

Podstawową tezą weryfikowaną w opracowaniu jest założenie o wpływie wskaźnika terms of trade polskich towarów rolno-żywnościowych na bilans wymiany tymi produktami z zagranicą. W badaniu podjęto próbę rozdzielenia tendencji krótko- i długookresowych w tym zakresie. W tym celu dokonano separacji szeregu czasowego wskaźnika terms of trade $\left(x_{t}\right)$ na wygładzony trend $g_{t}$ (składową wzrostu) oraz stacjonarną resztę $c_{t}$ (składową cykliczną). Rozdzielenia tego dokonano za pomocą filtra matematycznego $[F]$, którym jest operator transformacji danego wejściowego szeregu czasowego $\left\{x_{t}\right\}$ w wyjściowy szereg czasowy $\left\{z_{t}\right\}$, a przekształcenie nosi nazwę filtracji [Rinne, Specht 2002]:

$$
\left\{x_{t}\right\} \rightarrow[F] \rightarrow\left\{z_{t}\right\}
$$

Dekompozycji szeregu czasowego $x_{t}$ dokonano poprzez zastosowanie filtra Hodricka-Prescotta [Hodrick, Prescott 1997]. Stąd $x_{t}=g_{t}+c_{t}$, gdzie składowa trendu $g_{t}$ jest równa $g_{t} 2 g_{t-1}-\mathrm{g}_{\mathrm{t}-2}+\mathbf{e}_{\mathrm{t}}$. Składowa wygładzona $g_{t}$ jest wyznaczana poprzez optymalizację wyrażenia:

$$
\min \left[\sum_{t=1}^{T}\left(y_{t}-g_{t}\right)^{2}+\lambda \sum_{t=2}^{T-1}\left[\left(g_{t+1}-g_{t}\right)-\left(g_{t}-g_{t-1}\right)\right]^{2}\right]
$$

W badaniu oparto się na informacjach statystycznych z bazy Eurostatu. Szeregi czasowe polskiego sektora rolno-żywnościowego, które uwzględniono na poszczególnych etapach analizy to:

hpt_ToT - terms of trade - wartości wygładzone filtem Hodricka-Prescotta (\%),

hp_ToT - terms of trade - składowa cykliczna filtru Hodricka-Prescotta (\%),

$\mathrm{Bal}$ - saldo bilansu handlowego produktami rolno-żywnościowymi (mln euro),

Rat - relacja wartości eksportu do importu, 
GVA - wartość dodana brutto sektora rolnego (mln euro),

prod - produkcja sektora rolnego (mln euro).

Dane, których użyto do weryfikacji efektu HLM, miały częstotliwość roczną i obejmowały lata 2002-2017.

Estymacji parametrów modeli opisujących badane współzależności, wyznaczania wartości funkcji odpowiedzi na impuls $(I R F)$ oraz dekompozycji wariancji błędu prognozy dokonano za pomocą programu GRETL.

\section{WERYFIKACJA EFEKTU W POLSKIM SEKTORZE ROLNO-ŻYWNOŚCIOWYM}

Oszacowania wpływu szoków w cenowym wskaźniku terms of trade na saldo rachunku obrotów bieżących polskiego sektora agrobiznesu dokonano stosując model wiążący podobne zależności na poziomie makroekonomicznym [Kent, Cashin 2003]. Model Kenta i Cashina opisuje związek między poziomem produktu krajowego brutto (PKB), saldem rachunku obrotów bieżących a szokami terms of trade. W przypadku niniejszego badania rozpatrywano wartość dodaną brutto sektora rolnego.

Przyjęto, że na zmiany terms of trade składały się dwa elementy - wyodrębniony trend oraz komponent resztowy [Agenor, Aizenman 2000]. Rozróżnienia między długoi krótkookresowymi wahaniami cenowych terms of trade dokonano poprzez zastosowanie filtra Hodricka-Prescotta do wyznaczenia tendencji w tym zakresie. Szoki krótkookresowe identyfikowano jako cykliczne reszty otrzymane z wygładzonych szeregów czasowych. Zatem do oceny szoków trwałych i krótkookresowych skonstruowano oddzielne modele bazujące na metodologii VAR. Na podstawie pierwszego systemu równań modelu wektorowej autoregresji oceniano skutki trwałych zmian cenowego wskaźnika terms of trade na saldo rachunku obrotów bieżących. Drugi model posłużył do oceny efektu szoków krótkookresowych.

Ponieważ modele VAR wymagają stacjonarności zmiennych, konieczne było ustalenie tego aspektu danych. Zadania tego dokonano z wykorzystaniem testu KPSS, a wyniki przedstawiono $\mathrm{w}$ tabeli 1 . Zaprezentowane tam zmienne po uwzględnieniu $\mathrm{w}$ nich trendu cechują się własnością stacjonarności. Przyjęty poziom istotności $p=0,05$ dla niektórych cech jest warunkiem spełnionym na granicy istotności statystycznej. Przekształcenie danych przez różnicowanie w odniesieniu do każdej z nich skutkuje spełnieniem postulatu stacjonarności.

Tabela 1. Wyniki testów stacjonarności na podstawie testu KPSS

\begin{tabular}{lcccc}
\hline \multirow{2}{*}{ Zmienna } & \multicolumn{2}{c}{ Poziomy zmiennych } & \multicolumn{2}{c}{ Pierwsze różnice } \\
\cline { 2 - 4 } & Statystyka testu & $p$ & Statystyka testu & $p$ \\
\hline hpt_ToT-z trendem & 0,1430 & $p>0,05$ & 0,1479 & $p>0,05$ \\
$h p \_T o T-\mathrm{z}$ trendem & 0,1046 & $p>0,1$ & 0,1055 & $p>0,1$ \\
Bal $-\mathrm{z}$ trendem & 0,1384 & $p>0,05$ & 0,0820 & $p>0,1$ \\
Rat $-\mathrm{z}$ trendem & 0,0783 & $p>0,1$ & 0,1071 & $p>0,1$ \\
$G V A-\mathrm{z}$ trendem & 0,0996 & $p>0,1$ & 0,0793 & $p>0,1$ \\
prod $-\mathrm{z}$ trendem & 0,1010 & $p>0,1$ & 0,0799 & $p>0,1$ \\
\hline
\end{tabular}

Źródło: opracowanie własne na podstawie danych Eurostatu. 
W ocenie charakteru powiązań między zmiennymi systemu pomocny staje się test kointegracji. W wyniku testowania szeregu koncepcji konfiguracji modelu, finalnie charakter relacji między zmiennymi: wygładzona tendencja terms of trade (hpt_ToT), saldo bilansu handlowego produktami rolno-żywnościowymi $(\mathrm{Bal})$, wartość dodana brutto $(G V A)$ sektora rolnego badano metodą Johansena. Wyniki testu kointegracji dla wspomnianej koncepcji przedstawiono w tabeli 2 . Rezultat badania tam zamieszczony wskazuje na pełny rząd macierzy $\Pi$, ponieważ wartości statystyk testowych $\lambda_{\text {trace }}$ oraz $\lambda_{\max }$ kolejno nie pozwalają na utrzymanie hipotez o rzędzie macierzy $\Pi$ równym „0" $\left(\lambda_{\text {trace }}=\right.$ $=70,642 p=0,000)$, a w następnym kroku o pierwszym rzędzie macierzy $\Pi$ ( $\left(\lambda_{\text {trace }}=\right.$ $=24,853 p=0,009)$. Pełny rząd macierzy $\mathrm{w}$ teście kointegracji Johansena $\left(\lambda_{\text {trace }}=3,231 p=0,549\right)$ dla badanej relacji jest rekomendacją dla budowy modelu VAR dla poziomów zmiennych przedstawionego w postaci formuły (1).

Tabela 2. Badanie kointegracji zmiennych: $\left(h p t \_T o T\right),(B a l),(G V A)$ - test Johansena

\begin{tabular}{cccccc}
\hline \multirow{2}{*}{ Rząd macierzy } & \multirow{2}{*}{ Wartość własna } & \multicolumn{4}{c}{ Test kointegracji } \\
\cline { 3 - 5 } & & $\lambda_{\text {trace }}$ & $p$ & $\lambda_{\max }$ & $p$ \\
\hline 0 & 0,953 & 70,642 & 0,000 & 45,789 & 0,000 \\
1 & 0,763 & 24,853 & 0,009 & 21,622 & 0,004 \\
2 & 0,194 & 3,231 & 0,549 & 3,231 & 0,548 \\
\hline
\end{tabular}

Źródło: opracowanie własne na podstawie danych Eurostatu.

Oszacowania systemu wektorowej autoregresji dla konfiguracji zmiennych badanej testem kointegracji przedstawiono w tabeli 3 . W modelu uwzględniono zmienną egzogeniczną reprezentującą relację eksportu do importu rolno-żywnościowego w ujęciu wartościowym (Rat) oraz stałą (const) i zmienną czasową (time). Przedstawiony model wiąże wygładzone wartości cenowych terms of trade (hpt_ToT), co odpowiada zmianom długookresowym wskaźnika, z saldem rachunku obrotów bieżących sektora agrobiznesu. Podstawowe statystyki służące do oceny modelu wskazują na jego poprawność. W szczególności wartość statystyki $L B(3)=20,2513$; $d f=18$; $(p=0,3189)$ testu Portmanteau wskazuje na brak autokorelacji reszt dowolnego rzędu w systemie VAR. Pierwiastki równania charakterystycznego wynoszące: 1: $(0,9913,0,0000), 2:(0,2130,0,0597)$, 3: $(0,2130,-0,0597)$ mieszczą się w kole jednostkowym i świadczą, że otrzymane rozwiązanie jest stabilne.

Model składa się z trzech równań. Równanie pierwsze zaprezentowane w tabeli 3. opisuje relacje między zmiennymi systemu VAR, gdy zmienną zależną są długookresowe zmiany wskaźnika ToT $\left(\Delta h p t \_T o T\right)$. W równaniu istotne statystycznie są zmienne: wartości wygładzone terms of trade (hpt_ToT), saldo bilansu handlowego produktami rolno-żywnościowymi ( $\mathrm{Bal}$ ) oraz zmienna czasowa (time). Test przyczynowości (test $F$ dla hipotezy o braku restrykcji) wskazuje, że w objaśnianiu bieżących wartości wygładzonych terms of trade $\left(h p t \_T o T\right)(F(1,10)=210920 p=0,0000)$ pomocne są opóźnienia tej zmiennej i opóźnienia zmiennej $\operatorname{Bal}(F(1,10)=7,1863 p=0,0231)$. Trzecia zmienna (GVA) nie jest powiązana z pozostałymi składowymi systemu w tym równaniu $(F(1,10)=$ $=1,9599 p=0,1918$ ).

W równaniu drugim systemu VAR zmienną zależną jest saldo bilansu handlowego produktami rolno-żywnościowymi $(\mathrm{Bal})$. W równaniu tym statystycznie istotne są długo- 
okresowe zmiany ToT ( $h p t$ t ToT) oraz zmienna egzogeniczna odzwierciedlająca relację eksportu do importu (Rat). Parametr przy zmiennej Bal pozostaje na granicy istotności statystycznej. Ujemny znak przy oszacowaniu parametru dla $h p t$ ToT sugeruje negatywny kierunek zależności między zmianami terms of trade a saldem bilansu handlowego ( $\mathrm{Bal}$ ). Konkluzję tę wspiera wynik testu $F$ dla hipotezy o braku restrykcji. Test przyczynowości implikuje wpływ opóźnień długookresowych zmian terms of trade (hpt_ToT) na saldo bilansu handlowego produktami rolno-żywnościowymi $(F(1,10)=34,651 p=0,0002)$. Test przyczynowości nie ustanawia relacji między opóźnionymi i bieżącymi wartościami zmiennej zależnej w równaniu ze względu na marginalną istotność statystyczną $(F(1,10)$ $=3,3375 p=0,0977)$. W wyjaśnianiu zmiennej Bal nie są użyteczne również przeszłe wartości $G V A(F(1,10)=0,3195 p=0,5844)$. Podsumowując, oszacowania parametrów przedstawionego modelu wiążą trwałe zmiany cenowych terms of trade z poziomem salda rachunku obrotów bieżących.

Tabela 3. Oszacowania parametrów równań modelu VAR

\begin{tabular}{|c|c|c|c|c|}
\hline \multirow{2}{*}{ Zmienna } & Współczynnik & Błąd standardowy & $t$ - Studenta & \multirow{2}{*}{ Wartość $p$} \\
\hline & \multicolumn{3}{|c|}{ Oszacowania parametrów równania 1. modelu VAR: $\left(\Delta h p t \_T o T\right)$} & \\
\hline hpt_ToT_l & 1,003 & 0,002 & 459,258 & $<0,0001$ \\
\hline Bal_1 & 0,00007 & 0,000 & 2,681 & 0,023 \\
\hline$G V A \_1$ & $-0,00004$ & 0,000 & $-1,400$ & 0,192 \\
\hline Rat & 0,002 & 0,003 & 0,731 & 0,481 \\
\hline time & $-0,111$ & 0,025 & $-4,480$ & 0,001 \\
\hline \multicolumn{5}{|c|}{ Oszacowania parametrów równania 2. modelu VAR: $(\Delta B a l)$} \\
\hline hpt_ToT_l & $-85,825$ & 14,580 & $-5,887$ & 0,000 \\
\hline Bal_1 & 0,304 & 0,166 & 1,827 & 0,098 \\
\hline GVA_1 & 0,071 & 0,126 & 0,565 & 0,584 \\
\hline Rat & 96,722 & 14,615 & 6,618 & $<0,0001$ \\
\hline time & 118,068 & 108,400 & 1,089 & 0,302 \\
\hline \multicolumn{5}{|c|}{ Oszacowania parametrów równania 3. modelu VAR: $(\Delta G V A)$} \\
\hline hpt_ToT_1 & 70,444 & 41,839 & 1,684 & 0,123 \\
\hline Bal_l & $-0,193$ & 0,374 & $-0,515$ & 0,618 \\
\hline$G V A \_1$ & 0,110 & 0,215 & 0,512 & 0,620 \\
\hline Rat & $-53,380$ & 42,677 & $-1,251$ & 0,240 \\
\hline time & 548,982 & 178,388 & 3,078 & 0,012 \\
\hline
\end{tabular}

W równaniu opisującym kształtowanie się wartości dodanej brutto $(G V A)$ nie jest istotna statystycznie żadna ze składowych systemu VAR. Równocześnie test $F$ dla hipotezy o braku restrykcji nie identyfikuje relacji przyczynowości między zmiennymi systemu VAR, co oznacza nieistotność opóźnień każdej z tych cech w objaśnianiu $G V A((F(1,10)$ $=3,3375 p=0,0977)$. Konkluzję tę wspiera wynik testu $F$ dla hipotezy o braku restrykcji. Test przyczynowości implikuje wpływ opóźnień długookresowych zmian terms of trade (hpt_ToT) na saldo bilansu handlowego produktami rolno-żywnościowymi $(F(1,10)=$ $=34,651 p=0,0002)$. Test przyczynowości nie ustanawia relacji między opóźnionymi 
i bieżącymi wartościami zmiennej zależnej w równaniu ze względu na marginalną istotność statystyczną $(F(1,10)=3,3375 p=0,0977)$. W wyjaśnianiu zmiennej Bal nie są użyteczne również przeszłe wartości GVA (hpt_ToT: $F(1,10)=2,8348 p=0,1232 ;$ Bal: $F(1,10)=0,2652 p=0,6177 ; G V A: F(1,10)=0,2620 p=0,6198)$.

W przypadku krótkookresowych szoków cenowych terms of trade ( $\left.h p_{-} T o T\right)$ stworzenie systemu wektorowej autoregresji na podstawie podobnego zestawu zmiennych (Bal oraz GVA) nie doprowadziło to identyfikacji relacji przyczynowości między nimi. $\mathrm{W}$ żadnym z równań systemu VAR poszczególne składowe nie były również istotne statystycznie. Wynik taki należy interpretować jako niewystępowanie współzależności między krótkookresowymi zmianami cenowych terms of trade a saldem obrotów bieżących polskiego sektora rolno-żywnościowego w okresie badania.

Badanie przyczynowości między zmiennymi systemu VAR uzupełnia analiza wrażliwości modelu na szoki wywołane zmianami jego składowych, które nosi nazwę badania przebiegu funkcji odpowiedzi na impuls $(I R F)$. W formie graficznej wyniki te ukazuje rysunek 1. Impuls w zmiennych systemu podtrzymywany jest do trzech okresów od momentu wystąpienia, po czym na ogół szybko wygasa. W zmiennej hpt_ToT najsilniejszy efekt osiąga impuls z niej samej. Wyraźnie mniejszy skutek w hpt_ToT powoduje zaburzenie ze zmiennych Bal oraz GVA. Dodatkowo, impuls z GVA wygasa po jednym okresie. Zaburzenia ze zmiennych systemu są podtrzymywane w Bal o jeden okres krócej niż w hpt_ToT (dwa lata, ale znacznie słabnie po roku). Najsilniejszy oddźwięk wywołuje w Bal zakłócenie wywodzone z tej zmiennej. Efekt impulsu wyprowadzonego z hpt_ToT jest o jedną trzecią słabszy. Odpowiedź Bal na impuls z GVA jest bardzo słaba. Zaburzenia zmiennych systemu pozostawiają w $G V A$ jednookresowy ślad. Najsilniejszy efekt wywołuje w GVA impuls z tej zmiennej. Skutki zaburzenia z $h p t \_T o T$ są ponadtrzykrotnie słabsze. Impuls wyprowadzony ze zmiennej $G V A$ można uznać za nieznaczący.

Kolejnym, poza testowaniem przyczynowości i badaniem funkcji $I R F$, źródłem informacji o relacjach między zmiennymi systemu VAR jest analiza dekompozycji wariancji błędu prognozy, której rezultaty zaprezentowano w tabeli 4. Wyniki te reprezentują model z porządkiem zmiennych ( $\left.h p t \_T o T, B a l, G V A\right)$. Stabilizacja udziałów wariancji najdłużej dokonuje się w równaniu 1. (sześć okresów). W pozostałych równaniach do ustabilizowania udziałów dochodzi już w drugim roku. Z perspektywy badania najbardziej interesujące są udziały zmiennych po ustabilizowaniu (w ostatnim okresie). Dla przyjętej specyfikacji systemu po stabilizacji w równaniu 1. zmienna hpt_ToT jest wyjaśniana w 75,80\% własnymi wartościami oraz w 13,38\% wartościami zmiennej Bal i w 10,81\% wartościami zmiennej $G V A$. W równaniu 2. zmienna Bal jest wyjaśniana w 75,72\% własnymi wartościami oraz w 21,59\% wartościami zmiennej $h p t$ ToT i jedynie w 2,69\% wartościami zmiennej GVA. W równaniu 3. zmienna GVA jest wyjaśniana niemal wyłącznie własnymi wartościami (91,29\%). Udział zmiennej hpt_ToT wynosi 7,99\%, a wkład zmiennej Bal należy uznać za nieznaczący $(0,72 \%)$.

W świetle wyników analizy dekompozycji za najbardziej egzogeniczny czynnik należy uznać wartość dodaną brutto sektora rolnego $(G V A)$. Natomiast czynnikiem najbardziej endogenicznym jest saldo bilansu handlowego produktami rolno-żywnościowymi $(B a l)$, które jest wyjaśniane w najszerszym zakresie przez pozostałe zmienne. Zakres egzogeniczności długookresowych zmian terms of trade ( $h p t$ ToT) jest nieco większy niż zmiennej Bal. Obserwacje te są zgodne z wynikami testowania przyczynowości i z ogólną teorią ekonomiczną. 
Odpowiedź hpt ToT na impuls z hpt ToT

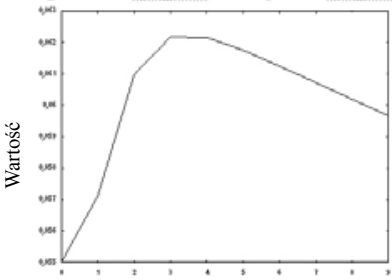

Odpowiedź Bal na impuls z hpt_ToT

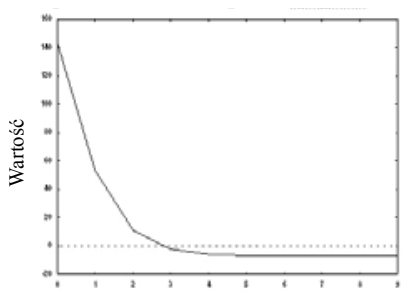

Odpowiedź GVA na impuls z hpt_ToT

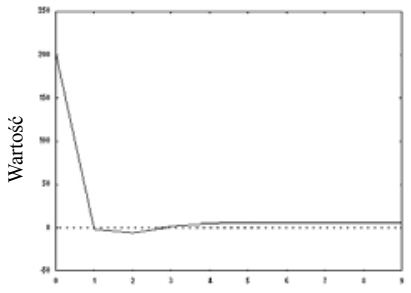

Odpowiedź $h p t$ ToT na impuls z Bal

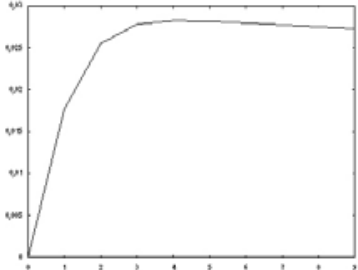

Odpowiedź Bal na impuls z Bal

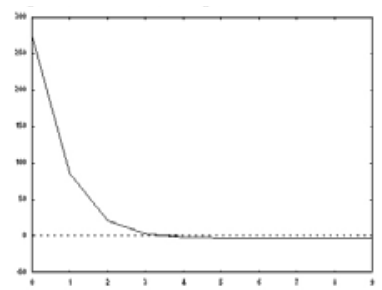

Odpowiedź GVA na impuls z Bal

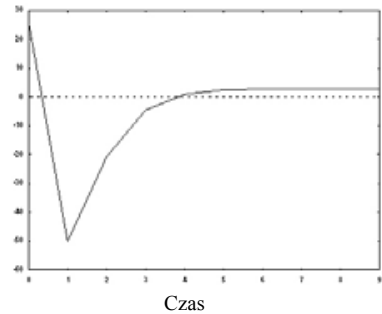

Odpowiedź $h p t$ ToT na impuls z GVA

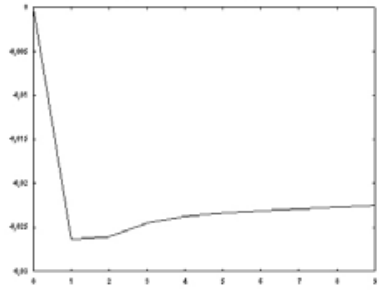

Odpowiedź Bal na impuls z GVA

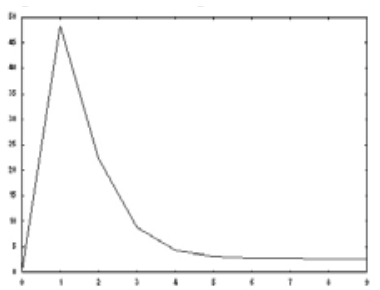

Odpowiedź GVA na impuls z GVA

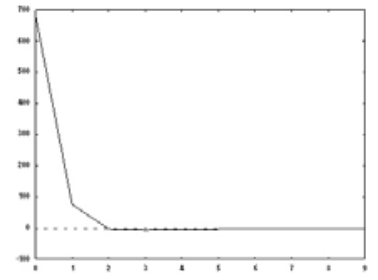

Rysunek 1. Funkcja odpowiedzi na impuls w modelu VAR

Źródło: opracowanie własne na podstawie danych Eurostatu.

\section{WNIOSKI}

Wyniki studium powiązań zmian cenowych terms of trade z saldem wymiany towarowej produktami rolno-żywnościowymi z zagranicą potwierdzają hipotezę HarbergeraLaursena-Metzlera w części odnoszącej się do trwałych zmian wskaźnika. Wyniki modelu opartego na metodyce wektorowej autoregresji (VAR) nie wspierają tezy o wpływie zmian krótkookresowych cenowych terms of trade na saldo bilansu handlowego rozpatrywanej grupy towarowej.

Metodyka wektorowej autoregresji nie wiąże się z koniecznością ustalania a prio$r i$ charakteru zmiennych $\mathrm{w}$ tworzonym modelu. $\mathrm{W}$ to miejsce postępowanie badawcze umożliwia ustalenie priorytetu składowych modelu oraz testowanie przyczynowości. W świetle badań najbardziej egzogenicznym czynnikiem jest wartość dodana brutto sektora rolnego. Pozostałe zmienne systemu VAR zasadniczo nie wpływają na nią. Czynnikiem najbardziej endogenicznym pozostaje saldo bilansu handlowego produktami rolnożywnościowymi. Zgodnie z teorią, stopień egzogeniczności długookresowych cenowych terms of trade jest większy od salda bilansu handlowego. Zmiany długookresowych 


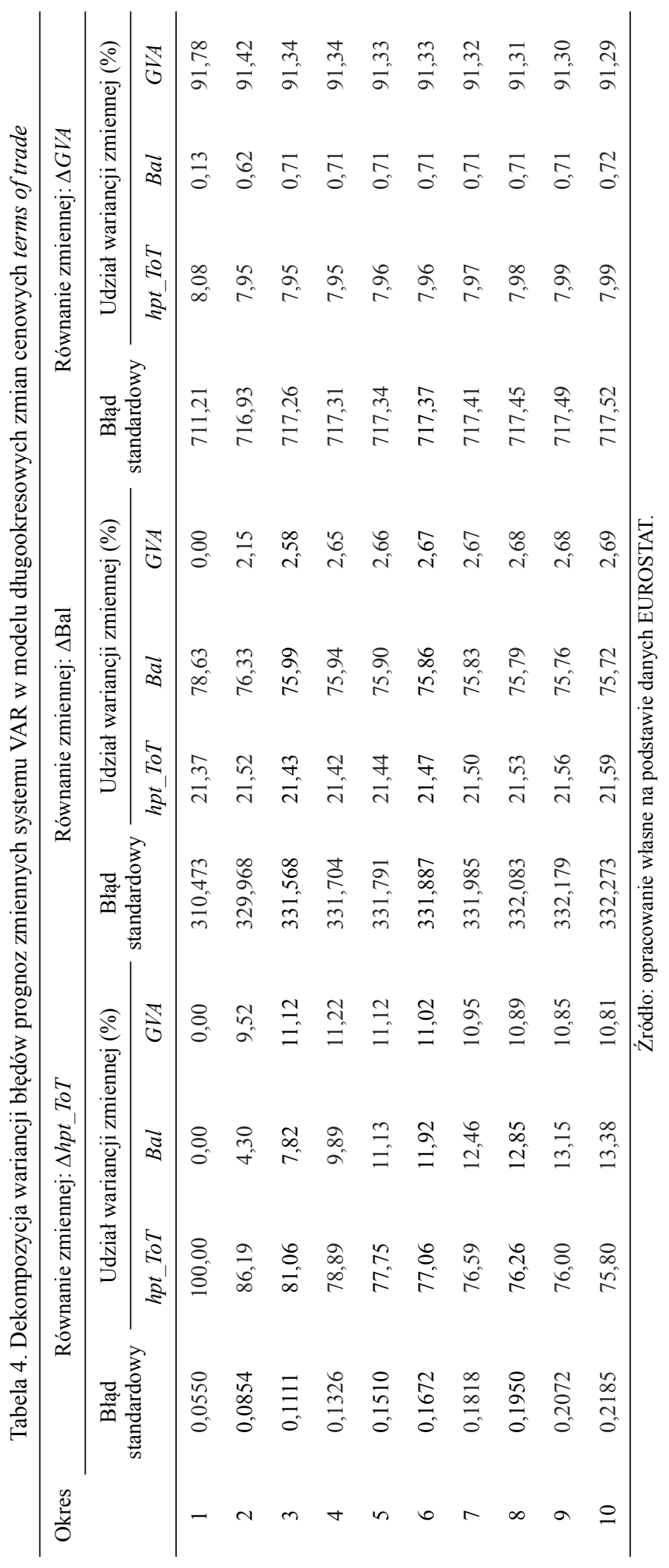


cenowych terms of trade kształtują w pewnym zakresie saldo bilansu handlowego produktami rolno-żywnościowymi i jest to relacja ujemna.

Ujemna wartość parametru oraz wysoka istotność statystyczna w modelu dla tendencji długookresowej sugeruje istotny wpływ malejącego cenowego terms of trade na poprawę bilansu handlowego polskimi produktami rolno-żywnościowymi. Współwystępowanie dwóch tendencji: poprawiającego się salda wymiany handlowej z zagranicą oraz stałego spadku cenowego terms of trade może implikować strategię konkurencji polskich produktów na rynku międzynarodowym opartą na czynniku cenowym. Jednak wskaźnik cenowy terms of trade nie wychwytuje ewentualnej poprawy efektywności wytwarzania oraz ogólnego zmniejszania kosztów produkcji, który może wynikać na przykład ze zwiększania skali działania. $Z$ tej perspektywy pogorszenie cenowego wskaźnika terms of trade nie wiąże się automatycznie z pogorszeniem warunków wymiany z zagranicą, a ogólne korzyści z handlu osiągane przez polski sektor rolno-żywnościowy mogą wykazywać w czasie tendencję rosnącą.

Dla krótkookresowych zmian cenowych terms of trade żaden $\mathrm{z}$ tworzonych modeli wektorowej autoregresji nie doprowadził do identyfikacji relacji przyczynowości między wskaźnikiem a saldem rachunku obrotów bieżących polskimi produktami rolno-żywnościowymi w okresie badania. Nie zidentyfikowano również istotnych statystycznie powiązań krótkookresowych terms of trade $\mathrm{z}$ osiąganą przez polskie rolnictwo wartością dodaną brutto.

\section{LITERATURA}

Agenor Pierre-Richard, Aizenman Joshua 2000: Savings and the Terms of Trade Under Borrowing Constraints, NBER Working Paper No. 7743, Cambridge, MA.

Charemza Wojciech, Deadman Derek 1992: New Directions in Econometric Practice, Edward Elgar Publishing, Aldershot.

Charemza Wojciech, Deadman Derek 1997: Nowa ekonometria, PWE, Warszawa.

Chowdhury Abdur 2003: Do asymmetric terms of trade shocks affect private savings in a transition economy?, Discussion Papers No. 3, Bank of Finland Institute for Economies in Transition, Helsinki.

Duncan Roberto 2003: The Harberger-Laursen-Metzler Effect Revisited: An Indirect-Utility-Function Approach, Central Bank of Chile Working Papers, No. 250, Santiago.

Eicher Theo Stefan, Schubert Stefan Franz, Turnovsky Stephen 2008: Dynamic Effects of Terms of Trade Shocks: The Impact on Debt and Growth, „,ournal of International Money and Finance", 27(6), s. 876-896.

Edwards Sebastian 1989: Temporary Terms of Trade Disturbances, the Real Exchange Rate and the Current Account, „Economica”, London School of Economics and Political Science, 56, s. 343-357.

Harberger Arnold 1950: Currency Depreciation, Income and the Balance of Trade, „Journal of Political Economy", 58, s. 47-60.

Hodrick Robert, Prescott Edward 1997: Postwar U.S. Business Cycles: An Empirical Investigation, „Journal of Money, Credit and Banking”, 29, 1, s. 1-6.

Johansen Soren 1988: Statistical Analysis of Cointegration Vectors, „Journal of Economic Dynamics and Control", 12 , s. 231-254. 
Kent Christopher, Cashin Paul 2003: The Response of the Current Account to Terms of Trade Shocks: Persistence Matters, IMF Working Paper, No. 143.

Kusideł Ewa 2000: Modele wektorowo-autoregresyjne VAR. Metodologia i zastosowania, Absolwent, Łódź.

Kwiatkowski Denis, Phillips Peter, Schmidt Peter, Shin Yongheol 1992: Testing the Null Hypothesis of Stationarity against the Alternative of a Unit Root. Journal of Econometrics, 54, s. 159-178.

Laursen Svend, Metzler Lloyd 1950: Flexible Exchange Rates and the Theory of Employment, „Review of Economics and Statistics”, 32, 4, s. 281-299.

Lütkepohl Helmut 1991: Introduction to Multiple Time Series Analysis, Springer-Verlag, BerlinHeidelberg.

Mendoza Enrique 1995: The terms of trade, the real exchange rate and economic fluctuations, „International Economic Review”, 36, 1, s. 101-137

Obstfeld Maurice 1981: Aggregate Spending and the Terns of Trade: Is There a Laursen-Metzler Effect?, Working Paper No. 686, NBER, Cambridge MA.

Osińska Magdalena 2006: Ekonometria finansowa, PWE, Warszawa.

Otto Glenn 2003: The Effect of Terms of Trade Shocks on the Trade Balance: Is There a HarbergerLaursen-Metzler Effect?, „Journal of International Money and Finance”, 22, 2, s. 155-184.

Persson Torsten, Svensson Lars 1985: Current Account Dynamics and the Terms of Trade: Harberger-Laursen-Metzler Two Generations Later, „Journal of Political Economy”, 93, s. 43-65.

Reinhart Carmen, Ostry Jonathan 1991: Private Saving and Terms of Trade Shocks, IMF Working Paper WP/91/100.

Rinne Horst, Specht Katja 2002: Zeitreihen. Statistische Modellierung, Schätzung und Prognose, Verlag Franz Vahlen, München.

Sachs Jeffrey 1981: The Current Account and Macroeconomic Adjustment in the 1970's, „Brooking Papers on Economic Activity", 1, s. 201-268.

Svensson Lars, Razin Assaf 1983: The Terms-of-Trade and the Current Account: The HarbergerLaursen-Metzler Effect, ,Journal of Political Economy”, 91, 97-125.

Turnovsky Stephen 1997: International Macroeconomic Dynamics, MIT Press, Cambridge. Wang Peijie 2009: The Economics of Foreign Exchange and Global Finance, Springer, Berlin.

Uzawa Hirofumi 1968: Time preference, the consumption function, and optimum asset holdings, [w] James Walk, ed., Value, capital, and growth: Papers in honour of Sir John Hicks, Aldine, Chicago, IL, s. 485-504.

\section{Jacek Strojny}

\section{AN ASSESSMENT OF HARBERGER-LAURSEN-METZLER EFFEKT IN AGRIBUSINESS SECTOR IN POLAND}

\section{Summary}

The aim of the study was to asses the Harberger-Laursen-Metzler effect in Polish agro-food sector. The analysis covers period of 2002-2017. There was applied the vector autoregression (VAR) methodology. The outcome of the research revealed that permanent deterioration in terms of trade contributed to the current account of Polish agribusiness sector improvement. The temporary effect of terms of trade 
shocks was not indentified. Additionally, the research enabled recognition of gross value added (GVA) as the most exogenous factor of the VAR system. On the other hand most endogenous factor of the model is the current account. The variable permanent terms of trade is more exogenous factor than the current account.

Adres do korespondencji: dr hab. Jacek Strojny (orcid 0000-0002-0577-377X) Uniwersytet Rolniczy im. Hugona Kołłątaja w Krakowie, Katedra Statystyki i Ekonometrii al. Mickiewicza 21, 31-120 Kraków e-mail: rrstrojn@cyf-kr.edu.pl 